\title{
Editorial
}

\section{Who can stop the rot?}

http://dx.doi.org/10.17159/2413-3108/2017/i61a3065

It is fitting that the first article in this issue of South African Crime Quarterly (SACQ) speaks to the South African Police Service's tackling of commercial crime. It is increasingly clear that corporate-political collusion poses a serious threat to South Africa's democratic gains. In recent months journalists have started to pick through a trove of emails released in June, known as the \#GuptaLeaks. In the process they have connected the dots between tens of thousands of exchanges among the notorious Gupta business family, managers of parastatals, government ministers and allies of President Jacob Zuma, including his son Duduzane. The emails paint a terrifying picture of state capture and abuse.

The Gupta family has rubbished the leaks, which appear to have come from within its own business empire, but some implicated ANC cadres have confirmed their authenticity. Nonetheless, until late August, when the SAPS Directorate for Priority Crime Investigation (better known as the Hawks) told Parliament that it was investigating aspects of the emails, little evidence in the public domain suggested that police or prosecutors were taking them very seriously. A week later, National Prosecuting Authority (NPA) head Shaun Abrahams confirmed to Parliament that the NPA's specialised commercial crime unit was investigating Gupta-linked contracts and state capture more broadly.

Among the most important revelations in the \#GuptaLeaks is strong evidence that R5.3 billion was paid to Gupta associates in kickbacks in 2014 locomotive deals between the South African parastatal Transnet and Chinese locomotive manufacturer, China South Rail (CSR). It seems that a Gupta friend, Salim Essa, used his company, Tequesta, to secure the contracts, together with Gupta associates at Transnet. A fee of R10 million for every R50 million locomotive purchased was included in the contract to be paid to Tequesta, simply for introducing CSR to Transnet. ${ }^{1}$

In another revelation, a Gupta-owned company, Estina, was paid R84 million and granted a feefree lease of thousands of hectares of land near Vrede in the Free State. The deal was ostensibly intended to drive agricultural empowerment projects for residents, but instead the money appears to have landed up in the United Arab Emirates, from where it was funnelled back to South Africa through and into other Gupta-owned companies. ${ }^{2}$ The deal was facilitated by current Minister of Mineral Resources Mosebenzi Zwane, who at the time was the Free State MEC for agriculture. Separately, but as suspiciously, Zwane launched a new mining charter in June this year, calling for rapid 'empowerment' in the sector. While few would dispute the need for South Africa's mining sector and economy at large to transform, Zwane's brash move resulted in the loss of R50 billion in JSE-listed mining stocks (a matter touched on in Mbekezeli Mzhize's article in this issue), possibly in part due to his questionable character and motivations in light of the \#GuptaLeaks. ${ }^{3}$ 
Both revelations - the locomotive and agricultural deals - hint at the degree to which business people and politicians, many linked to Gupta and Zuma networks, have colluded to fleece the South African fiscus in recent years. What's more, the emails confirm suspicions that the Guptas' Oakbay Capital employed British public relations firm Bell Pottinger to craft strategies to defend the Zuma and Gupta families and their allies from mounting accusations of state capture. ${ }^{4}$ Beginning in early 2016, Bell Pottinger staff wrote speeches and prepared talking points for Gupta and Zuma allies, which were in turn spread by Gupta-owned media outlets and Twitter bots in an enormously powerful 'fake news' operation. ${ }^{5}$ The firm charged over R1.5 million a month as a retainer for its divisive services.

In early September, following a formal complaint by the Democratic Alliance, Bell Pottinger was expelled by the United Kingdom's Public Relations and Communications Association, ditched by shareholders, and widely condemned, including in the British Parliament and by the British High Commissioner to South Africa, for running a racially divisive campaign that has damaged British relations with South Africa. And yet, while the global public relations firm crumbles, its Gupta-Zuma clients carry on as before.

In part because of the \#GuptaLeaks, and following a Constitutional Court ruling on the matter, Parliament on 8 August voted in a secret ballot in response to an opposition-led motion of no confidence in Zuma. While an unprecedented number of ANC MPs voted with the opposition, Zuma survived yet again with 198 votes against the motion, 177 for, and nine abstentions. All eyes are now on the ANC's December National Conference, which marks the end of Zuma's term as ANC president, and thus perhaps the ANC's last chance to get its house, and the country, in order.

\section{This issue}

It is hard, considering the consolidation of political and economic power revealed in the \#GuptaLeaks, to imagine how South Africa's criminal justice system will stem the looting of the state. But what about commercial crime on a more modest scale? In the first article in this issue, Trevor Budhram and Nicolaas Geldenhuys use SAPS performance data to suggest that the SAPS is losing the battle against even relatively minor commercial crime. With a focus on detection rates, they convincingly argue that the SAPS performance is unjustifiably weak, and that this weakness is hidden behind the inclusion of unfounded and withdrawn cases, and the classification of whole dockets (which can include multiple charges) as single charges in its accounting systems. They suggest that this makes the SAPS look more efficient than it is, obscuring its inability to address commercial crime. In so doing, they add to a growing body of literature highlighting the pitfalls of performance targets in policing.

Next, John Kole asks whether private security officers (PSOs) could better support the SAPS crime prevention mandate if they had more legal authority. To explore this question, Kole presents data from interviews and a survey carried out with senior private security and SAPS managers, as well as with operational officers. Current legislation limits PSOs from acting beyond their capacity as private citizens. To many it is obvious that more armed, uniformed men and women with the authority to stop, search and detain suspected law-breakers will reduce crime. However, Kole questions whether more police would mean less crime. Evidence from elsewhere in the world suggests that it would not. ${ }^{6}$ Furthermore, the proposal that PSOs be given more authority is not supported by the police or 
private security managers he interviewed. Even if they did, do we really want to coerce and punish ourselves towards a more just South Africa? Our sentencing policies suggest that we do.

South Africa has harsh minimum sentences, supported by the logic that serious crime deserves serious punishment. ${ }^{7}$ As a result, South Africa's 236 prisons, designed to accommodate 119134 inmates, in 2016 housed 161 984. ${ }^{8}$ In this issue, Emma Lubaale compares South African and New Zealand court decisions, asking whether South African courts can better balance custodial and restorative sentences. She suggests that South African courts perceive restorative justice sentences as weak, and shows that courts in New Zealand have used them to address serious crime. A 2015 report from the Brennan Center for Justice at New York University found that imprisonment in the US has had almost no effect on crime rates since the early 1990s. ${ }^{9}$ This is because once prison populations reach a certain level, imprisonment has diminishing crime deterrence returns. Surely this is true of South Africa, too? If so, Lubaale's call for a balance between custodial and restorative sentences is one worth taking seriously.

South Africa's Child Justice Act (2008) promotes the principles of restorative justice for young offenders. But where can young ex-offers turn for support after serving a sentence? In his article, Sean Larner takes us inside the Rebuilding and Life Skills Training Centre (Realistic) in Gugulethu, Cape Town, and into the lives of some of the young ex-offenders who have been through its programmes. Using in-depth interviews, the article presents a case study examining the obstacles faced by young ex-offenders and the impact of Realistic's aftercare programme on their lives.

In our last research article, Cyrus Arwui, Victor Tshivhase and Rudolph Nchodu offer insight into the formulation of Design Basis Threat (DBT) statements for nuclear facilities. DBTs are recommended by the International Atomic Energy Agency as a methodology to secure radioactive sites. The higher the risk ascertained by the DBT, the more capable security systems must be. Referring to the formulation of a DBT for the Irradiation Facility at the Centre of Applied Radiation Science and Technology in Mafikeng, the article offers a fascinating insight into the types of data used and assumptions made in the formulation of a DBT, including what some might believe to be an overreliance on reported crime numbers (not rates) in nearby towns. This raises questions about the veracity of such DBT methodologies.

Finally, in a commentary and analysis piece, Mbekezeli Mkhize reviews the challenges and opportunities posed by illegal artisanal (small-scale) mining in South Africa. He argues that the forces that push migrant miners away from their rural homes, often in neighbouring states, and pull them towards illegal mining activities, can only be addressed through an integrated network-governance response, involving a multiplicity of actors and resources.

I hope that you enjoy the issue.

\section{A final word}

This is my last issue as editor of SACQ. The experience has been a pleasure and an honour. I am immensely grateful for the support of former (wonder) editor, Chandré Gould, and the fabulous SACQ production team of Bea Roberts, Iolandi Pool and Janice Kuhler. I am also grateful to Chandré and Mark Shaw, former director of the Centre of Criminology at the University of Cape Town (UCT), for affording me this opportunity. I greatly appreciate all the technical support and encouragement 
provided by Ina Smith, Susan Veldsman and their colleagues at the Academy of Science of South Africa, and for the wisdom shared by members of the SACQ editorial board.

Subsequent issues will be edited by Kelley Moult, Nolundi Luwaya, Diane Jefthas and colleagues at the Centre for Law and Society, UCT. I hope that you will join me in wishing them well.

\section{Andrew Faull}

(Editor)

\section{Notes}

1 amaBhungane and Scorpio, \#GuptaLeaks: Guptas and associates score R5.3bn in locomotives kickbacks, 1 June 2017, http:// amabhungane.co.za/article/2017-06-01-guptaleaks-guptas-and-associates-score-r53bn-in-locomotives-kickbacks (accessed 31 August 2017).

2 amaBhungane and Scorpio, \#GuptaLeaks: The Dubai Laundromat - how millions from dairy paid for Sun City wedding, 30 June 2017, http://amabhungane.co.za/article/2017-06-29-guptaleaks-the-dubai-laundromat (accessed 31 August 2017).

3 A Seccombe, Mine Charter axe falls on mining stocks, renders sector 'uninvestable', Business Day, 19 June 2017, https://www. businesslive.co.za/bd/companies/mining/2017-06-19-mine-charter-axe-falls-on-mining-stocks-renders-sector-uninvestable/ (31 August 2017).

4 Scorpio and amaBhungane, \#GuptaLeaks: How Bell Pottinger sought to package SA economic message, Daily Maverick, 6 June 2017, https://www.dailymaverick.co.za/article/2017-06-06-scorpio-and-amabhungane-guptaleaks-how-bell-pottinger-sought-topackage-sa-economic-message/\#.WagDcz4jGUI (accessed 31 August 2017).

5 amaBhungane, Daily Maverick and News24, \#GuptaLeaks: Direct evidence Gupta henchmen prepared fake race-baiting tweet, 23 June 2017, http://www.news24.com/SouthAfrica/News/guptaleaks-direct-evidence-gupta-henchmen-prepared-fake-racebaiting-tweets-20170623 (accessed 31 August 2017).

6 JM Ogilvie, TJ Allard and AL Stewart, Impact of police numbers on crime, JMAG, December 2008; S Levitt and T Miles, Economic contributions to the understanding of crime, Annual Review of Law and Society, 2, 2006, 147-64; A Chalfin and J McCrary, The effect of police on crime: new evidence from US cities 1960-2010, National Bureau of Economic Research, 2013, http://www. nber.org/papers/w18815 (accessed 1 September 2017); B Bradford, Police numbers and crime rates: a rapid evidence review, HM Inspectorate of Constabulary and Fire \& Rescue Services, 2011, https://www.justiceinspectorates.gov.uk/hmicfrs/media/policenumbers-and-crime-rates-rapid-evidence-review-20110721.pdf (accessed 1 September 2017); W Skogan and K Frydl (eds.), Fairness and effectiveness in policing: the Evidence Committee to review research on police policy and practices, National Research Council, 2004.

7 L Muntingh, 'Sentencing', in C Gould, Criminal (in)justice in South Africa: a civil society perspective, Pretoria: Institute for Security Studies, 2008.

8 Judicial Inspectorate for Correctional Services, Annual report 2015/16, http://judicialinsp.dcs.gov.za/Annualreports/JICS\%20 Annual\%20Report\%20\%202015-2016\%20as\%20at\%204\%200ctober\%202016\%20v\%2012.pdf (accessed 31 August 2017).

9 O Roeder, L-B Eisen and J Bowling, What caused the crime decline? New York: Brennan Center for Justice, New York University, 2015. 